\title{
The Sun about Heliocentric Theory in Science Perspective and Al-Qur'an Tafsir al-Maraghi
}

\author{
${ }^{1}$ Umul Jazila*, ${ }^{2}$ Suliyanah \\ ${ }^{1,2}$ Universitas Negeri Surabaya (UNESA), Jl. Lidah Wetan, East Java, Indonesia \\ *jazila.zila99@gmail.com
}

\begin{abstract}
This study aims to analyze the sun as the centre of the solar system in the heliocentric theory from the point of view of physics and the Qur'an. The research method used is a qualitative research method with library research (Library Research). The results of this study are proof of the truth that in the Qur'an, there is also a science that explains the heliocentric theory, which states that the sun is the centre of the solar system. Based on the idea of Nicolaus Copernicus in a book entitled De Revolutionibus Orbium Coelestium, it has been published that the heliocentric theory can overthrow the long-established geocentric theory. The Qur'an was revealed long before the astronomical concept of the earth's motion was put forward and was in line with the heliocentric view. In the Al-Qur'an, there are verses about the world, moon and sun, for example, Yunus: 5, al-Naml: 88, and Yasin: 38-40. The sun as the centre of the solar system is not static but also in motion. This is explained in the AlQur'an in Surah Yasin verses 38-40. Ahmad Mustafa al-Maraghi in Tafsir al-Maraghi emphasized that the heliocentric theory is by the Qur'an and the birth of the heliocentric idea is part of the miracle of Al-Qur'an.
\end{abstract}

Penelitian ini bertujuan untuk menganalisis matahari sebagai pusat tata surya pada teori heliosentris dalam sudut pandang fisika dan Al Qur'an. Metode penelitian yang digunakan yaitu metode penelitian kualitatif dengan jenis penelitian pustaka (Library Research). Hasil penelitian ini merupakan pembuktian kebenaran bahwa dalam Al Qur'an juga terdapat ilmu yang menjelaskan mengenai teori heliosentris yang menyatakan mengenai matahari sebagai pusat tata surya. Berdasarkan teori Nicolaus Copernicus pada buku berjudul De Revolutionibus Orbium Coelestium telah dipublikasikan bahwa teori heliosentris mampu meruntuhkan teori geosentris yang telah lama mapan. Al-Qur'an diwahyukan jauh sebelum dikemukakan konsep astronomi tentang gerak bumi dan selaras dengan teori heliosentris. Dalam Al-Qur'an terdapat ayat-ayat tentang bumi, bulan dan matahari misalnya surat Yunus: 5, al-Naml: 88, dan Yasin: 38-40. Matahari sebagai pusat tata surya tidaklah statis melainkan juga bergerak. Hal ini dalam Al-Qur'an dijelaskan dalam surat Yasin ayat 38- 40. Ahmad Mustafa al-Maraghi dalam Tafsir al-Maraghi menegaskan bahwa teori heliosentris sesuai dengan Al-Qur'an dan lahirnya teori heliosentris merupakan bagian dari mu'jizat Al-Qur'an.

Keywords: Heliocentric Theory, Science, and Tafsir al-Maraghi.

Received: November 16, 2020; Revised: December 26, 2020; Accepted: Decmber 27, 2020 


\section{INTRODUCTION}

The universe is inseparable from the world of science. Science is a tangible result of human thought that brings a particular perspective in understanding an event or reality. Astronomy is a branch of science that deals with celestial bodies and natural phenomena outside Earth's atmosphere. The standpoint of scientific thought in the field of astronomy is still a paradigm debate that never ends. Much evidence currently assumes that NASA's findings are untrue. Lately, there has been a lot of discussion about familiar things and have long been debated by scientists, namely the real centre of the solar system. The United States has reportedly succeeded in sending the first man on the moon and desires to set foot for the first time on Mars in 2030. It turned out that shocking news was obtained about the results of a research survey in a survey institution that was conducted in 2012 involving 2,200 respondents with the question "Is the earth that revolves around the sun or vice versa, the sun that circles the earth?" turned out to produce an unexpected answer. The National Science Foundation revealed that 1 in 4 respondents answered the second; this is considered a problematic condition regarding science education throughout the US.

Based on the old paradigm, the sun's theory as the centre of the universe was first coined by a Greek scientist named Aristarchus (3rd century BC). This opinion was refuted by another Greek philosopher named Aristotle, who lived in 384-322 BC. There was no denial during the 15 centuries - then reinforced by a scientist named Ptolemy who lived in 151-127 BC and was not disputed during the 12 centuries. Nicolas Copernicus, who lived in 1473-1543 AD reading Aristarchus' books, finally revived the theory that the earth and other planets revolve around the sun. Copernicus thought a sun-centred solar system was more logical and beautiful but had no definite proof (Hambali, 2013a). Kepler found that the laws governing orbits were much simpler when the Sun was at the centre. Newton had shown that this was due to the universal law of gravity. If gravity works, the earth and other planets have to circle the sun because it is much more significant. Based on the new paradigm, the earth's revolution is the world's motion in its orbit around the sun. The plane of the earth's orbit around the sun is called the ecliptic. During its orbit around the sun, the earth's axis is always tilted $23.5^{\circ}$ to the perpendicular to the ecliptic. The orbits of the other planets are not on the same level as the ecliptic. The angle between the orbital plane of another world and the ecliptic is called the inclination (Orderay, 1971).

Islam is the last divine religion sent down by Allah SWT through His Messenger, Muhammad SAW with the holy book of the Koran which is complete with various information, including those concerning the universe, specifically those related to the motion of the sun, earth, and month. Allah SWT revealed the Qur'an to Prophet Muhammad SAW through the angel Jibril in the 7th century AD, at that time science had not developed as it is today. Still, the Qur'an has provided important information which has proved to be a lot at the time. Now. In 1543 AD, due to the revolution of Copernicus (a Polish jurist and astronomer), there was a lot of resentment, especially among church clergy. The cause was Copernicus's opinion which was contrary to his religious doctrine. Nicolaus Copernicus suggested that celestial bodies' motion would be more straightforward if the sun were seen as the centre of the universe. Nicolaus Copernicus firmly said that it is not the sun that moves around the earth as Ptolemy's view was held for that time but quite the opposite. Earth, along with other celestial bodies moving around the sun. Copernicus succeeded in lowering the earth from an honourable position. Now the earth's abdication is replaced by a very hot object, the 
sun. This theory is known as the heliocentric theory. Nicolaus Copernicus (1473$1543 \mathrm{M}$ ) was a Polish philosopher armed with scientific facts dared to bring up views (hypotheses) about the sun's solar system, which was very controversial in his time, namely the heliocentric idea.

The history of Islam's development cannot be separated from science, although currently, the Islamic world is left behind by the western world in terms of science (Ikhwan, 2016). One of the many sciences that have experienced triumphs in the Islamic world is astronomy, known in the Islamic world as astronomy. Among the mufassirin of the Al-Qur'an, there are different opinions regarding the interpretation of the Al-Qur'an verses, which are related to Astronomy, especially the concept of the rotation of the earth and the sun. This difference disturbs the author to examine it from the review of the Al-Qur'an and science by scientific principles commonly used. The development of astronomy in the Islamic world began with the large-scale translation of astronomical works from Greece and India into Arabic (Qulub, 2018). One of which is translated is Ptolemy's famous work, Almagest, which is centred in Baghdad, the scientific culture in the Islamic world is increasing. Ptolomeous maintained that the earth was the centre of the universe and that everything moved around it (Coote $\&$ Coote, 2004).

Conversely, Copernicus stated that it would be more comfortable in theory and calculations by replacing the earth's position with the sun as the universe's centre. This theory is known as Heliocentric (Dobrzycki, 1972). Long before Copernicus stated his Heliocentric idea, Ibn Al-Syatir, an expert on the Damascus Muwaqqit (1304-1375), said about Mercury's intricacies motion if Earth were the centre of the solar system (Halimah, 2018). It could be that Ibn Al-Syatir's theory was the beginning of the birth of the Heliocentric idea. Although the Heliocentric approach already stands on solid ground, there are not a few who refute it. From the Muslims themselves, there are differences of opinion between the mufassirin in interpreting the verses of the Qur'an related to astronomy, some agree with the Heliocentric theory, but some interpret the earth does not move. Still, the sun is moving (QS 35:41, 36:38 etc.) according to the Geocentric theory (Dasen \& Mishra, 2010). According to several groups, there is a clash of scientific reviews and the Al-Qur'an according to several groups in the concept of the rotation of the earth and the sun above. Science has proved quite accurately that the sun is the centre of our solar system, and all the planets, including the world, rotate around it. Those who argue against the Heliocentric theory also have a strong foundation, namely the Al-Qur'an as a way of life for Muslims (Khozin, 2004).

There are many different paradigms by scientists about the theory of the centre of the universe, making a review of the basis of science obtained from the school level which says the sun is the centre of the solar system. This review needs to be based on empirical evidence that is consistent with the relevant theory and results. Al-Qur'an can provide phenomena that are essentially the theoretical basis of humans, so it is necessary to study how the sun is the centre of the solar system in the heliocentric theory based on physics and the Al-Qur'an.

\section{METHOD}

The research method used is qualitative research methods with the type of library research. The technique used in this research is a descriptive qualitative research 
method to the kind of library research. Library research is a series of activities related to collecting library data through reading, recording and processing research data (Zed, 2017). The approach used in this research is a qualitative descriptive research approach as an approach that is expected to bring the best results later. Qualitative research is research whose findings are not obtained through statistical processors or other means of qualification. Sources of data from primary data sources and secondary data sources, Primary data sources are data sources that directly provide data to researchers. Meanwhile, secondary data sources are data sources that do not now provide data to data collectors. Data analysis using technique that the researchers used was the Milles and Huberman model analysis technique, checking the wetness of the data using steps: 1) Data reduction; 2) Data presentation or data display; 3) Conclusion or verification, the focus of research is to prove the truth of the Qur'an regarding the heliocentric theory, regarding the sun as the centre of the solar system, so that it is thoroughly discussed Islam about the universe can be used as the primary reference about modern science.

\section{RESULT AND DISCUSSION}

This section presents the results of the research conducted. The research results obtained include the sun as the centre of the solar system in the heliocentric theory, evidence of the sun as the centre of the solar system based on scientists, and the sun as the centre of the solar system Al-Qur'an.

\section{The sun as the centre of the solar system in the heliocentric theory}

The heliocentric theory assumes that the sun is the centre of circulation of the planets, including the earth, while the moon circles the world which then together the earth rotates around the sun. The sun is just spinning around its axis. It is currently known that there are nine planets in the solar system, namely: Mercury, Venus, Earth, Mars, Jupiter, Saturn, Uranus, Neptune and Pluto, all of which revolve around the sun. For the last one, Pluto, it is disputed whether it is a planet in the solar system of the sun or not.

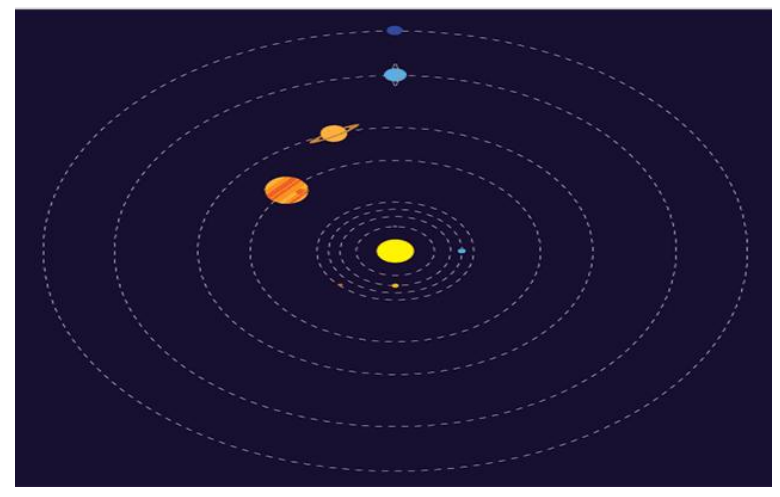

Figure 1. Illustration of the heliocentric theory

Nicolaus Copernicus was not the first to come up with the heliocentric theory. Previously in the 13th century BC, a Greek philosopher named Aristarchus expressed the hypothesis that the earth and the planets revolved around the sun. Aristarchus's opinion was not in line with Aristotle's (384 BC-322 BC) opinion so that Aristarchus' heliocentric theory was marginalized by geocentric theory. The geocentric theory 
considers the earth to be the centre of rotation of the stars and planets, including the sun and moon.

Nicolaus Copernicus' major work entitled "De Revolutionibus Orbium Coelestium" (On the Circular Revolution of Celestial Bodies) describes his theory in detail and puts forward his proofs. At that time, it was challenged by many, including the Lutherans, who were the first to call the book De Revolutionibus Orbium Coelestium "absurd". Although initially not expressing criticism, the Catholic Church decided that De Revolutionibus Orbium Coelestium contradicted its official doctrines. In 1616 AD Nicolaus Copernicus's heliocentric theory also received significant attention from philosophers afterwards. After making long and in-depth observations and research, the philosophers confirmed, supported and perfected Nicolas Copernicus' heliocentric theory. They include Isaac Newton (1642-1727 AD), Galileo Galilei (1564-1642 AD) and Johannes Kepler (1571-1630 AD). Nicolaus Copernicus is praised by many and given the nickname as the Father of Modern Astronomy. Even the astrophysicist Owen Gingerich stated that "Copernicus was the one who showed us how fragile scientific concepts that have been accepted for a long time". Through observation, research and mathematics Copernicus overturned entrenched but erroneous scientific and religious concepts.

\section{Evidence of the sun as the centre of the solar system based on scientists}

Some scientists express some of their thoughts related to the earth's revolution around the sun. Their knowledge is expressed through natural phenomena that occur. The first scientist to suggest that the sun is the centre of the solar system is Nicolaus Copernicus, a theory that is quite famous, which he initiated is the heliocentric theory. Copernicus wrote a book entitled De Revolutionibus Orbium Coelestium, which then undermined the geocentric view established and used as a reference for centuries (Hambali, 2013b).

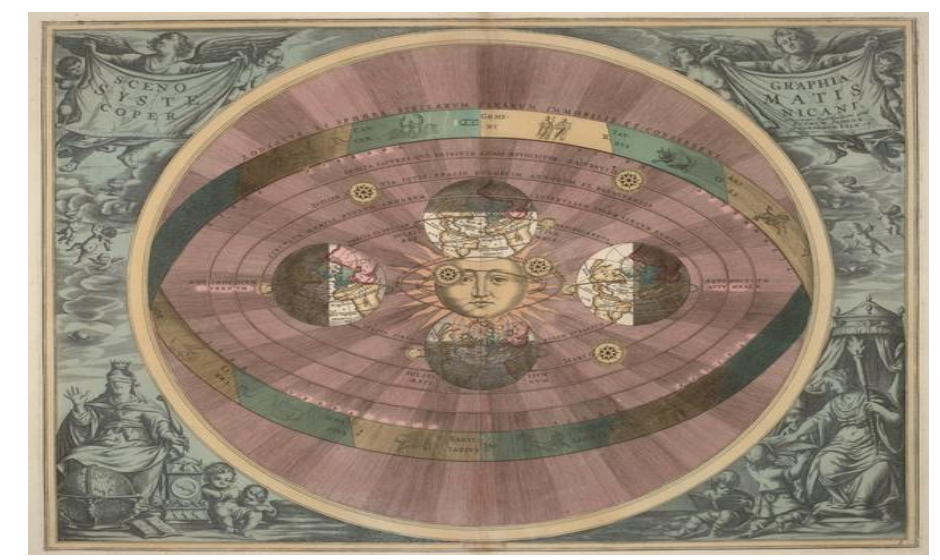

Figure 2. The sun is the centre of the solar system which was initiated by Nicolaus Copernicus

Apart from Copernicus, several scientists proved it through his experiments. The following is proof of the studied scientists:

The first evidence is found by James Bradley (1725), who found the existence of star aberrations. The illustration of the explanation is like imagine we are standing in the middle of the rain and the rainwater falls strictly vertically or perpendicular to our heads. If we use an umbrella, our leader's face and back will not be splashed with water. Then we start strolling forward and walking faster, and it is as if the rainwater 
that had fallen earlier will bend and splash our faces. To avoid this, we tend to lean the umbrella forward. The rainwater still falls perpendicularly, but we move relatively forward, so the effect that occurs is as if it turns and splashes on our faces.

Likewise with the phenomenon of stellar aberration, actually the position of the star is always fixed at a point in the sky. Still, from astronomical observations, the star's part has shifted from its starting point, the shift is not too large but sufficient to show that the earth is moving (Rausi, 2019).

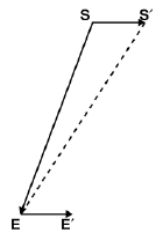

Figure 3. The analogy of proving star aberration

Aberration occurs when an observer is a person standing in the rain, and the direction of the starlight is the direction of the rainwater falling. Then the observer moves straight ahead, perpendicular to the direction of the shower. S represents the position of the star, E is the position of the observer on earth. The star's actual path relative to the observer is ES, its distance depending on the speed of light. Then the world moves in the direction EE 'with the direction of the line representing its speed. It turns out that observations show that the star is on the line ES 'instead of ES, with SS' parallel and equal to EE '. Then, the star's visible position is shifted from its actual position with the angle formed between SES '. If the Earth is not moving, then for every time, the angle SES 'is 0, but it turns out that the angle SES' is not zero. This is the first proof that the earth is moving (Firdaus \& Sinensis, 2017).

The second evidence is the parallax of the stars. This evidence was first measured by Bessel (1838). Parallax can occur when the position of a distant star appears to be moving towards a closer star. This phenomenon can only happen because of a change in the lead's part due to the movement of the earth towards the sun. This change in position forms an angle $\mathrm{p}$ if we take the edges' functions when the Earth circles the Sun. The parallax angle, expressed as (p), is the half parallactic shift when the star is observed from the two most extreme positions.

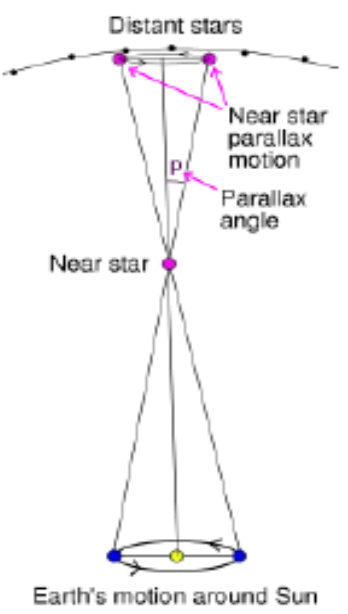

Figure 4. Star parallax 
How can we explain this phenomenon? This can only be explained if the earth revolves around the sun, and not vice versa.

The third evidence is the Doppler effect. As was introduced by Newton, that it turns out that light can be broken down into natural components, then the knowledge of starlight becomes a useful source of information about how stars are fingerprinted. It turns out that astronomical observations show that many stellar behaviours indicate that many celestial objects have misplaced fingerprints (Nabil, 2018). The explanation was given by Doppler (1842), that is a source of information 'moves' (this information can be sound or an optical source), then the information changes. This can happen because the movement is relative, whether because the observer is moving, or because the head is moving (Midas, 1986).

Likewise, if the light source approaches, the observed light waves will become bluer in light sources, the reverse will be redder. As the earth moves closer to the star, the star becomes more down, and as it moves away, it becomes redder. At one point the star's observations show a red shift, but the star experiences a blue shift. This is proof that it turns out that the earth is moving back and forth because it is orbiting the sun, has speed relative to the stars and is not just standing still (Putra, 2015).

Thus, there is three supporting evidence that the earth moves around the sun, from aberrations (small changes in star position due to the speed of the planet), parallax (changes in the place of stars due to changes in Earth's work) and the Doppler effect (changes in star colour due to the speed of the Earth). In my opinion, this evidence strongly supports that the centre of the solar system is the sun (Rahmnan et al., 2017).

\section{The sun as the centre of the solar system in the Al-Qur'an}

Al-Qur'an as a revelation from Allah SWT which comes directly from Allah SWT has provided information about the universe, especially those related to the sun, moon and earth. Twenty verses mention the word sun, 463 verses mention the word earth, and five verses mention the moon. Not to mention the verse that explains the sky, the alternation of day and night, and the verse that says the stars. Related to the heliocentric theory, several verses describe the sun's motion, moon and earth, namely the letter Yunus: 5, Yasin: 38, and al-Naml: 88. Some of these verses are:

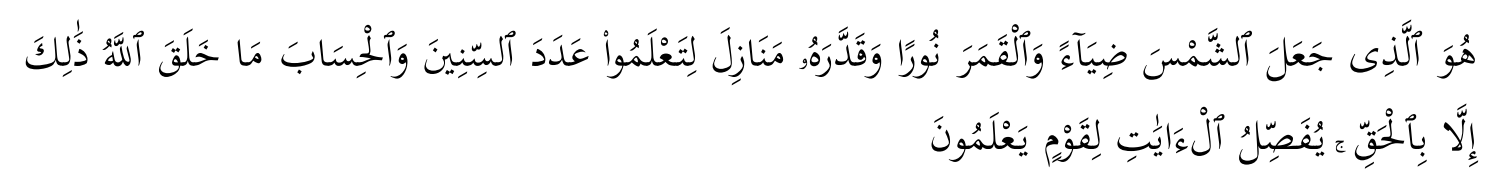

"He was the one who made the sunshine and the moonshine, and He appointed manzilah (places) for the lunar journey so that you would know the number of years and calculations (time). God did not create it, but with such rights. He explains the signs (of His greatness) to those who know". (Yunus [10]: 5).

In the letter Yunus verse 5, Allah mentions two celestial bodies: the sun and the moon. Allah explains the existence of Allah's decree regarding the places where the moon travels (essentially the moon circulates the earth in one synodic month an average of 29 days 12 hours 44 minutes. 2.8 seconds). There is no explanation about the journey of the sun (if the mafhūmmukhālafah is taken, it means that the sun does not circulate the earth) (Al-Marāghī, 1974).

In particular, Allah explains the journey of the sun in Surah Yasin verse 38: 


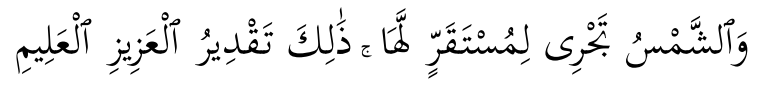

"And the sun goes in its circulation. Such is the determination of the Almighty, the All-knowing". (Yasin [36]: 38).

In the explanation, the word "li mustaqarrin" لمستقر al-Maraghi interprets it around the dwelling place of the sun. Al-Maraghi said "It is truly unique, dear readers of the Qur'an. Why does the Qur'an have established something which is then shown to be accurate by present discoveries and refutes the opinions that were stated in the time of the Qur'an's revelation. 'an among the astronomers from Greece, India and China. "AlMaraghi once met and asked Abdul Hamid Samahah, the binoculars leader in Egypt who is located in Hulwan about things that have become resolutions of current astronomers, about the theories contained in the verses of the Qur'an. Then Abdul Hamid wrote to Al-Marāgh as follows (Al-Marāghī, 1974).

First Evidence: Change of Day and Night. Among the evidence of Allah SWT's power with His beautiful creations is the existence of changes, which are continually changing day and night. This has been mentioned many times in the Qur'an because considering this astronomical phenomenon is very important for the life of humanity and other creatures that live on earth (Masnur, 2011). This verse of Allah SWT includes things that should be considered to be used as evidence of the greatness of the creator. The night is sorted from day and day from night. As a result of the earth's rotation around its axis from west to the east called the earth's rotation, the sun appears on the eastern horizon and sets on the western horizon in a very orderly and beautiful manner (Shihab, 2002). This evidence strongly supports that the solar system centre is the sun where the earth surrounds its axis, which causes the change of day and night.

Second Evidence: The Absolute Motion of the Sun. The sun is outwardly seen to make an annual cycle amid the stars due to the earth circulating the sun once a year called the earth's revolutionary motion. It is proven by experts recently that the sun also has other essential movements: first, the sun circulates on its axis one time every about 26 days. This is shown by observing sunspots, which are black spots that appear on the surface from time to time, which are not fixed on the sun's surface and travel the distance between two sun spheres within 13 days (Azhari, 2007). Second, the sun's circulation with all the celestial bodies that are its followers, namely the planets and with their respective moons around the centre of the universe (star system) at a speed of about 200 miles per second. So the sun is one of the millions of stars that make up this universe, and it is evident that the universe or star system circulates its centre. Therefore, the sun is not fixed in its centre, but it has a circular motion. Based on the scientists' understanding, the word "li mustaqarrin" in surah Yasin verse 38 means a fixed axis where the rotating motion is centred on it or means the circular centre of the movement. With the first meaning, "li mustaqarrin" means the line that stretches between the sun's two poles. While in the second sense "li mustaqarrin" means the centre of the whole star system where all the stars revolve around the sun (Azhari, 2005). In my opinion, this evidence strongly supports that the centre of the solar system is the sun. Where the sun itself also moves not static.

Third Evidence: The Sun's Pseudo Motion. As has been said, the sun is circulating the earth in an outward motion, resulting from the world's circulation around the sun. Physical movements like those felt by train passengers when they see trees, telephone poles and villages seem to move without feeling their actions because they are on the 
train. The sun's movement as a result of the circulation of the earth around the sun in the middle of the other stars on a vast orbit with a diameter of 93 million miles (Sidiq $\&$ Ikhwan, 2018). The earth revolves around the sun once in a complete rotation in one year. The sun's movement indicates a movement like this in the middle of the sun by the standard of one cloud per month, or one degree every day. As for the motion of the earth, as explained in the letter al-Naml: 88 :

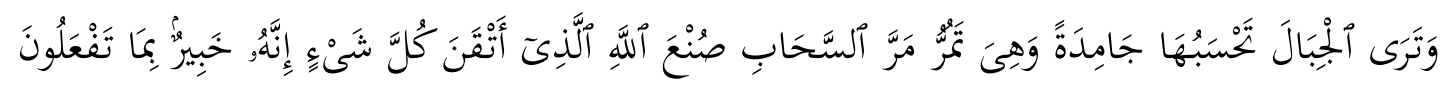

"And you look at the mountains, you think that he is still where he is, but he walks as the path of the clouds. (That is) Allah's act firmly makes each thing; Verily, Allah knows what you are doing". (an-Naml [27]: 88).

Mountains are part of the earth, so to say they walk as the paths of the clouds. This indicates that the planet is walking as the path of the shadows. In this case, Clouds are certainly not appropriate if given the essential meaning, namely clouds that become rain. It would be by the development of modern science if the importance of magazine, namely clouds, is defined as clusters of stars in the sky at night when the sky is clear with no rain and no clouds, and the stars are visible as clouds. In astronomy, it is stated that the earth has four kinds of motion, namely rotation, revolution, precession and nutation (Nursodik, 2016). In my opinion, this evidence strongly supports that the centre of the solar system is the sun where there is a pseudo-motion of the sun caused by the rotation of the earth towards the sun.

\section{CONCLUSION}

A conclusion Nicolas Copernicus' heliocentric theory has proven the correctness of the science brought by the Al-Qur'an. The verses of the Al-Quran clearly show that there is no conflict with modern science, especially in the perspective of science related to astronomy, even though the Qur'an was revealed long before the heliocentric theory, namely in the 7th century AD. The Koran's argument about the truth of the centre of the solar system was emphasized by Ahmad Mustafa al-Maraghi in his tafsir alMaraghi when interpreting the letter Yasin: 38. Through an analysis of three astronomical evidence of events, namely: the change of day and night, the necessary motion of the sun, and the apparent motion of the sun, al-Maraghi concluded that there is an exact correspondence between the heliocentric theory taught by the Qur'an and the idea of modern astronomy or science. The conformity of the verses of the Qur'an with modern science, according to al-Maraghi, is also a part of the miracle of the Koran that can indeed be proven.

\section{REFERENCES}

[1] Al-Marāghī, A. M. (1974). Tafsīr al-Marāoghī, Juz 23, trans. Anwar Rasyidi. Mesir: Mușțafā al-Bābī 'l-Ḥalabī.

[2] Azhari, S. (2005). Hisab Rukyat Encyclopedia. Yogyakarta: Student Library.

[3] Azhari, S. (2007). Imu Falak, Khazanah encounter and Modern Science. Yogyakarta: Voice of Muhammadiyah.

[4] Coote, R. B., \& Coote, P. M. (2004). Kuasa, Politik $\mathcal{E}$ Proses Pembuatan Al Kitab: 
Suatu Pengantar. Jakarta: PT BPK Gunung Mulia.

[5] Dasen, P. R., \& Mishra, R. C. (2010). Development of Geocentric Spatial Language and Cognition: An Eco-cultural Perspective. Inggris Raya: Cambridge University Press.

[6] Dobrzycki, J. (1972). The Reception of Copernicus' Heliocentric Theory. Poland: Ossolineum.

[7] Firdaus, T., \& Sinensis, R. (2017). Revolutionary Theory Paradigm Debate: Sun or Earth as the Center of the Solar System. Titian Ilmu: Multi Science Scientific Journal, 9(1).

[8] Halimah, S. N. (2018). Benang Merah Penemu Teori Heliosentris: Kajian Pemikiran Ibn Al-Syāțir. Al-Marshad: Jurnal Astronomi Islam Dan Ilmu-Ilmu Berkaitan, 4(1), 135145.

[9] Hambali, S. (2013a). Astronomi Islam Dan Teori Heliocentris Nicolaus Copernicus. Al-Ahkam, 23(2), 225. https://doi.org/10.21580/ahkam.2013.23.2.24

[10] Hambali, S. (2013b). Islamic Astronomy and Heliocentric Theory of Nicolaus Copernicus. Al-Ahkam, 23(2), 225-236.

[11] Ikhwan, A. (2016). Perguruan Tinggi Islam dan Integrasi Keilmuan Islam: Sebuah Realitas Menghadapi Tantangan Masa Depan. At-Tajdid: Jurnal Ilmu Tarbiyah, 5(2), 160.

[12] Khozin, M. (2004). Science of Falak in Theory and Practice. Yogyakarta: Buana Pustaka.

[13] Masnur, H. (2011). Al-Maraghi (Pemikiran Teologinya). An-Nida' Jurnal Pendidikan Islam, 36(2), 260-271.

[14] Midas, S. (1986). al-Jaylanī, K.H. Zubayr 'Umar, al-Khulāșah al-Wafiyyah fĩ 'l-Falaq bi Jadwāl al-Lughatimiyyah. Kudus: The Holy Tower.

[15] Nabil. (2018). Pendidikan Ilmu Astronomi Dari Historis Sampai Heliosentris. Marhalah: Jurnal Pendidikan Islam, 2(2), 93-110.

[16] Nursodik. (2016). 8. Tinjauan Fikih dan Astronomi Kalender Islam Terpadu

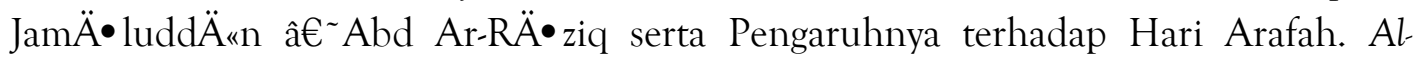
Manahij, 10(1), 145-154. Diambil dari http://library1.nida.ac.th/termpaper6/sd/2554/19755.pdf

[17] Orderay, R. (1971). Earth Scienc. Reinhold: Van Nostrand.

[18] Putra, T. (2015). Tafsir al-Maraghiy. Jakarta: PT Mizan Pustaka.

[19] Qulub, S. T. (2018). Integrasi Astronomi dalam Ilmu Falak di PTAI dan Pondok Pesantren. Jurnal Pemikiran dan Pembaharuan Hukum Islam, 21(2), 288-309.

[20] Rahmnan, A. A., Rivai, M., \& Tasripan, T. (2017). Sistem Otomatisasi Pelacakan Objek Astronomi Menggunakan Teleskop Berdasarkan Stellarium. Jurnal Teknik ITS, 6(2), 521-526. https://doi.org/10.12962/j23373539.v6i2.24121

[21] Rausi, F. (2019). Astrolabe; Instrumen Astronomi Klasik Dan Kontribusinya Dalam Hisab Rukyat. Elfalaky, 3(2), 120-137. https://doi.org/10.24252/ifk.v3i2.14149

[22] Shihab, M. Q. (2002). Tafsir al-Mishbah. Jakarta: Heart Lantern. 
[23] Sidiq, U., \& Ikhwan, A. (2018). Local Government Policy Regarding Mandatory Students Diniyah Takmiliyah in Indramayu Regency. KARSA: Journal of Social and Islamic Culture. https://doi.org/10.19105/karsa.v26i1.1444

[24] Zed, M. L. (2017). Research Methods. Jakarta: Yayasan Pustaka Obor Indonesia. 